\title{
Editorial
}

\section{Circulating Immune Complexes in Diabetes}

\author{
U. Di Mario, M. Iavicoli, and D. Andreani \\ Cattedra di Endocrinologia, Clinica Medica II, Policlinico Umberto I, Roma, Italy
}

Over the last few years more sensitive, reproducible and in some instances more specific techniques for the detection of circulating immune complexes $(\mathrm{AgAb})$ have been developed [1-4]. Using these newer techniques immunological aspects of various diseases have been reappraised, and the presence of $\mathrm{AgAb}$ in diabetes has also been investigated.

The interest in immune phenomena in diabetes has been increasing progressively. In the 1960s several studies, originating from the immunological implications of heterologous insulin administration, suggested that immune mechanisms could be of importance in the aetiology of diabetic microangiopathy. Morphological similarities with other immunological disorders were described [5-7], immune components were found in microangiopathic vessels [8-11], and diabetic - like lesions were experimentally induced by immune mechanisms especially in the renal glomeruli [12-14].

In the 1970s works by different authors provided a completely new outlook on the pathogenesis of insulin dependent diabetes. Clinical studies had shown a suggestive relationship between insulindependent diabetes and other organ specific autoimmune diseases $[15,16]$. It was then reported that in insulin-dependent diabetes [17-18] there was a modification in the cell-mediated immune response [19-21], an association with particular HLA antigens [22-24], and finally the presence of autoantibodies against islet cells was demonstrated [25-27].

In 1977 Irvine et al. using a single sensitive method [28] reported an increase in circulating immune complexes (AgAb) in some insulin-dependent diabetics at the time of diagnosis as well as in treated diabetics. Since then other investigators have confirmed an increase in $\mathrm{AgAb}$ in many diabetics, and have shown a correlation between the presence of $\mathrm{AgAb}$ and various diabetic conditions [29-39].

Before proceeding further it is necessary to delineate precisely what can be measured by the
$\mathrm{AgAb}$ methods. The solid phase CIq binding test, the Raji cell radioimmune assay and the conglutinin binding assay are some of the most sensitive techniques presently available [4, 40]. These methods are antigen non - specific and may be influenced by immunoglobulin aggregates but not by DNA, bacterial endotoxins and heat induced aggregates. The CIq method detects mainly complexes in antigen excess through the Fc portion of immunoglobulin aggregates, whilst the other two methods reveal complexes near the equivalence point, mostly through the third component of the complement. The complexes detected by all these methods are potentially harmful since they may activate the complement system or react with those cells bearing receptors for complexed immunoglobulins or the complex bound complement (namely lymphocytes and macrophages). The antigens involved in the complex formation may be either part of a cell membrane and secondarily shed into the circulation as a complex or non-cellbound antigens. In the latter situation complexes may be formed either in the circulation, with subsequent localisation in vessel walls or perivascular tissues, or locally in certain organs or tissues. As the methods presently available do not distinguish between complexes related to specific disease processes and those found in other more common conditions, e.g. viral infections, it is not surprising that circulating $\mathrm{AgAb}$ are also found in some apparently healthy subjects. Thus in evaluating the presence of $\mathrm{AgAb}$ in a particular disease it is important to compare the results with those found in a large normal population and to select an appropriate limit of positivity [41]. Differences in these basic points may explain some of the discrepancies between the various reported data.

In 1978 the increase in circulating $\mathrm{AgAb}$ in newly diagnosed insulin-dependent diabetics was confirmed in a large series of patients compared with agematched healthy controls using two different and sensitive methods [35]. In most of the patients $\mathrm{AgAb}$ 
tend to disappear within a few months of diagnosis and the decline is similar to that of islet cell antibodies (ICAb). Interestingly a significant association between the presence of $\mathrm{AgAb}$ and the occurrence of $\mathrm{ICAb}$ has been found at diagnosis and over the next few months. It is of particular interest that in a minority of insulin-dependent diabetics in which $\mathrm{ICAb}$ persist for some years after diagnosis circulating $\mathrm{AgAb}$ are increased [36]. The presence of circulating $\mathrm{AgAb}$ in newly diagnosed and untreated insulin-dependent diabetics did not correlate with titres of antivirus antibodies or with insulin antibody levels in insulin-treated diabetics within the first year of diagnosis (unpublished observations).

The significance of the presence of soluble $\mathrm{AgAb}$ in the serum of a large number of insulin-dependent diabetics near the time of diagnosis could be explained simply as a secondary effect of the immunopathological phenomena occurring in the islets or as a consequence of a normal immune response towards exogenous agents or viruses. $\mathrm{AgAb}$, on the other hand, could be involved in the islet cell damage through the activation of plasma components or of cells. The temporary presence of $\mathrm{AgAb}$ at the time of diagnosis of insulin-dependent diabetes may tie together some of the histological and immunological findings in the pathogenesis of this form of diabetes: the transient lymphocytic infiltration [42], the temporary presence of antibodies reacting with islets $[27,43,44]$, and the increased $\mathrm{K}$-cell activity in newly diagnosed cases $[44,45]$.

The presence of circulating AgAb has also been reported in a small but statistically significant percentage of diabetics $[31,33,34]$ more than one year after diagnosis. Theoretically various factors might influence the formation of circulating $\mathrm{AgAb}$, namely age and sex of the patient, type of treatment, insulin antibody levels, degree of metabolic control, latent infections, and the presence of complications. Studies using a Clq method on a randomly selected diabetic population have revealed an increase in circulating $\mathrm{AgAb}$ in insulin-treated diabetics, expecially in those with a duration of disease between 10 and 20 years compared with diabetics treated by diet or oral hypoglycaemic agents [38]. Furthermore a correlation between insulin antibody titres and AgAb levels has been reported. Complexes in diabetics with high insulin binding capacity levels tend to be undetectable by Clq methods [46]). This negative correlation may possibly be explained by the presence of low affinity insulin antibodies, the antigenic bivalency of insulin and the fact that $\mathrm{Clq}$ detects complexes in $\mathrm{Ag}$ excess. Thus data presently available suggest that at least some of the $\operatorname{AgAb}$ found in insulin treated diabetics are related to insulin treatment.
Circulating $\operatorname{AgAb}$ have also been studied in patients with late diabetic complications. In the past the presence of circulating complexes was suggested in order to explain a few clinical, morphological and experimental findings in patients with severe microangiopathy $[47,48,49]$. These studies present various difficulties because of the many factors involved in diabetic microangiopathy and the variables that should be taken into account. The type of diabetes, the different types of treatment, the time from diagnosis, the degree of metabolic control, and the type and severity of complications are of importance in these studies. The results in the literature are contradictory. Nevertheless when selected groups of diabetics with microangiopathy have been studied using a technique based on C1q properties, a correlation appears between the presence of $\mathrm{AgAb}$ and the occurrence of severe microangiopathy. $\mathrm{AgAb}$ were significantly lower in long-standing diabetics with no sign of microangiopathy than in comparable diabetics with severe microangiopathy (either proliferative retinopathy or severe nephropathy). $\mathrm{AgAb}$ were significantly higher in diabetics presenting with severe retinopathy within a few years of diagnosis including malignant microangiopathy [50] than in comparable diabetics without microangiopathy [37, 39]. $\mathrm{AgAb}$ found in patients with severe microangiopathy do not seem to have any correlation with the type of treatment or the insulin antibody titres. This finding is in keeping with the clinical observation that microangiopathy occurs irrespective of the type of treatment. These results suggest that a heterogeneous population of immune complexes, most of which are not related to insulin treatment, are present in certain patients with severe microangiopathy. Enhancement of $\mathrm{AgAb}$ levels could be due to an increased rate of production or a decreased rate of clearance of the complexes. As most AgAb detected by currently available methods are cleared by the reticuloendothelial cells lining the blood vessels, it is worth noting that impaired phagocytic clearance seems to be present in the majority of patients with severe microangiopathy [39].

According to the present state of our knowledge, it is tempting to speculate that an increase in soluble antigen-antibody complexes (due to impaired phagocytic clearance) in patients with severe microangiopathy may contribute to the vascular damage after passive binding or trapping of $\mathrm{AgAb}$ in the small vessel walls and in the perivascular tissues.

At present the detection of circulating antigennon-specific complexes is an unsatisfactory indirect measurement of more complex immune phenomena occurring elsewhere. Purification and identification of antigens involved in the complexes, careful follow- 
up of patients and a better understanding of the dynamics involved in the formation and clearance of $\mathrm{AgAb}$ are now necessary in order to evaluate the significance of immune complexes in diabetes.

\section{References}

1. Hay FC, Nineham LJ, Roitt IM (1976) Routine assay for the detection of immune complexes of known immunoglobulin class using solid phase C1q. Clin Exp Immunol 24:396-400

2. Theofilopoulos AN, Wilson CB, Dixon FJ (1976) The Raji cell radioimmune assay for detecting immune complexes in human sera. J Clin Invest 57: 169-182

3. Casali P, Bossus A, Carpentier NA, Lambert PH (1977) Solid phase enzyme immunoassay or radioimmunoassay for the detection of immune complexes based on their recognition by conglutinin: conglutinin - binding test. A comparative study with 125-I labelled $\mathrm{C} 1 \mathrm{q}$ binding and Raji-cell RIA tests. Clin Exp Immunol 29: 342-354

4. Lambert PH, Dixon FJ, Zubler RH, Agnello V, Cambiaso C, Casali P, Clarke J, Cowders JS, McDuffie FC, Hay FC, MacLennan ICM, Masson P, Muller-Eberhard HJ, Penttinen K, Smith M, Tappeiner G, Theofilopoulos AN, Verroust P (1978) A WHO collaborative study for the evaluation of 18 methods for detecting immune complexes in serum. J Clin Lab Immunol 1: 1-15

5. Blumenthal HT, Hirata Y, Owens CT, Berns AW (1964) A histo and immunological analysis of the small vessel lesion of diabetes in the human and in the rabbit. In: Siperstein MD, Colwell AR, Meyer K (eds) Small blood vessel involvement in diabetes mellitus. Am Inst Biol Sci 279-287

6. Bloodworth JMB (1968) Diabetic microangiopathy. In: Endocrine pathology. Williams \& Wilkins, Baltimore, p 389-412

7. Andreani D, Negri M, De Martino C (1971) Diabetic nephropathy. In: Pfeiffer EF (ed) Diabetes mellitus. Lehmans Verlag, Munich, p 684-718

8. Freedman P, Peterson JH, Kark RM (1960) Localization of gamma globulin in the diseased kidney. Arch Intern Med 105: 524-535

9. Berns AW, Owens CT, Hirata Y, Blumenthal HT (1962) The pathogenesis of diabetic glomerulosclerosis. II A demonstration of insulin binding capacity of the various histopathological components of the disease by fluorescence microscopy. Diabetes 11: $308-317$

10. Coleman SL, Becker B, Canaan S, Rosenbaum L (1962) Fluorescent insulin staining of the diabetic eye. Diabetes 11: 375-377

11. Westberg NG, Michael AF (1972) Immunohistopathology of diabetic glomerulosclerosis. Diabetes 21: 163-174

12. Andreev D, Ditzov S, Dashev G (1970) Diabetes-like vascular lesions in the kidneys of guinea pigs immunized with an insulin-adjuvant mixture. Acta Diabetol Lat 7: 243-255

13. Mohos SC, Hennigar GR, Fogelman JA (1963) Insulininduced glomerulo-sclerosis in the rabbit. J Exp Med 118: $667-680$

14. Zampa GA, Mancini AM (1965) Kimmestiel-Wilson-like nephropathy. Lancet II: 300

15. Irvine WJ, Clarke BF, Scarth L, Cullen DR, Duncan LJP (1970) Thyroid and gastric autoimmunity in patients with diabetes mellitus. Lancet II: 163-168

16. Nerup J (1974) The clinical and immunological association of diabetes mellitus and Addison's disease. In: Bastenie PA, Gepts W (eds) Immunity and autoimmunity in diabetes mellitus. Excerpta Medica, Amsterdam, p 149-152
17. Irvine WJ (1977) Classification of idiopathic diabetes. Lancet I: $638-642$

18. Cudworth AG (1978) Type I diabetes mellitus. Diabetologia 14: 281-291

19. Nerup J, Ortved Andersen O, Bendixen G, Egeberg J, Poulsen JE (1973) Antipancreatic cellular hypersensitivity in diabetes mellitus. Antigenic activity of fetal calf pancreas and correlation with clinical type of diabetes. Acta Allergol 28: 231-249

20. Nerup J, Ortved Andersen O, Bendixen G, Egeberg J, Gunnarsson R, Kromann H, Poulsen JE (1974) Cell mediated immunity in diabetes mellitus. Proc R Soc Med 67: 506-513

21. MacCuish AC, Jordan J, Campbell CJ, Duncan LJP, Irvine WJ (1974) Cell-mediated immunity to human pancreas in diabetes mellitus. Diabetes 23: 693-697

22. Nerup J, Platz P, Ortved Andersen O, Christy M, Lyngsoe J, Poulsen JE, Ryder LP, Staub Nielsen L, Thomsen M, Svejgaard A (1974) HL-A antigens in diabetes mellitus. Lancet II: 864-866

23. Cudworth AG, Woodrow JC (1975) HL-A system and diabetes mellitus I. Diabetes 24: 345-349

24. Morris PJ, Vaughan H, Irvine WJ, McCallun CJ, Gray RS, Campbell CJ, Duncan LJP, Farquhar JW (1976) HLA and pancreatic islet cell antibodies in diabetes. Lancet II: 652-653

25. Bottazzo GF, Florin-Christensen A, Doniach D (1974) Isletcell antibodies in diabetes mellitus with autoimmune polyendocrine deficiencies. Lancet II: 1279-1282

26. MacCuish AC, Irvine WJ, Barnes EW, Duncan LJP (1974) Antibodies to pancreatic islet cells in insulin-dependent diabetics with coexistent autoimmune disease. Lancet II: 1529-1531

27. Lendrum R, Walker G, Gamble DR (1975) Islet-cell antibodies in juvenile diabetes mellitus of recent onset. Lancet $\mathrm{I}$ : $880-882$

28. Irvine WJ, Al-Kateeb SF, Di Mario U, Feek CM, Gray RS, Edmond B, Duncan LJP (1977) Soluble immune complexes in the sera of newly diagnosed insulin dependent diabetics and in treated diabetics. Clin Exp Immunol 30: 16-21

29. Kumar D, Quismorio FP Jr (1978) Circulating immune complexes in diabetic patients. Diabetes 27 (Suppl 2): 221

30. Ludwig H, Schernthaner G, Albini B, Kano K (1978) Circulating immune complexes in insulin dependent diabetes mellitus. Diabetologia 15: 251

31. Kumar M, Zeidler A, Quismorio FP Jr (1979) Circulating immune complexes, islet-cell and insulin antibodies. Diabetes 28: 378

32. Schernthaner G, Ludwig H, Tappeiner G, Mayer WR (1979) Circulating immune complexes (CiC) IgG insulin antibodies (IAb). Islet cell antibodies (ICA) and HLA antigens in insulin dependent diabetes. Diabetes 28: 378

33. Balestrieri G, Tincani A, Fadini R, Cattaneo R, Saibene V, Valentini U, Moraschini A, Spotti D (1979) Circulating immunocomplexes in diabetes mellitus. Proceedings of the Symposium on Autoimmune Aspects of Endocrine Disorders, Pisa, 1979, p 44

34. Ludwig H, Schernthaner G, Tappeiner G (1979) Circulating immune complexes in insulin dependent diabetes: analysis according to incidence of islet cell antibodies, insulin antibodies HLA antigens, age at onset and duration of disease. Proceedings of the Symposium on Autoimmune Aspects of Endocrine Disorders, Pisa, 1979, p 28

35. Irvine WJ, Di Mario U, Guy K, Feek CM, Gray RS, Duncan LJP (1978) Immune complexes in newly diagnosed insulin dependent (Type I) diabetics. J Clin Lab Immunol 1: 183-186

36. Irvine WJ, Di Mario U, Guy K, Duncan LJP (in press) Immune complexes and islet cell antibodies in long standing diabetics. J Clin Lab Immunol 
37. Irvine WJ, Di Mario U, Guy K, Iavicoli M, Pozzilli P, Lumbroso B, Andreani A (1978) Immune complexes and diabetic microangiopathy. J Clin Lab Immunol 1: 187-191

38. Di Mario U, Iavicoli M, Ventriglia L, Galfo C, Bellagamba C, Andreani A (1979) Circulating immune complexes in long standing diabetics. Satellite Symposium to the 10th Congress of the International Diabetes Federation, Budapest, September 16-20, 1979, p 9

39. Di Mario U, Iavicoli M, Ventriglia L, Galfo C, Bellagamba C, Trionfera G, Cicconetti C, Andreani D (1979) Immune complexes, microangiopathy and metabolic control in diabetes. In: Waldhäusl WK (ed) Diabetes 1979. Excerpta Medica, Amsterdam, pp 379-382

40. WHO Scientific Group Report (1977) The role of immune complexes in disease. WHO, Geneva, 6

41. Di Mario U, Guy K, Irvine WJ (in press) Circulating immune complexes in normal subjects. J Clin Lab Immunol

42. Gepts W (1976) Islet changes suggesting a possible immune aetiology of human diabetes mellitus. Acta Endocrinol (Kbh) 83 (Suppl 205): 95-106

43. Lernmark A, Freedman ZR, Hofmann C, Rubenstein AH, Steiner DF, Jackson RL, Winter RJ, Traisman HS (1978) Islet cell surface antibodies in juvenile diabetes mellitus. $\mathrm{N}$ Engl $\mathrm{J}$ Med 299: 375-380

44. Huang SW, MacLaren NK (1976) Insulin dependent diabetes: a disease of autoaggression. Science 192: 64-66
45. Pozzilli P, Sensi M, Gorsuch A, Bottazzo GF, Cudworth AG (1979) Evidence for raised $\mathrm{K}$ cell levels in type I diabetes. Lancet II: $173-175$

46. Iavicoli M, Di Mario U, Pozzilli P, Di Nichilo M, Andreani D, (1980) Immune complexes and insulin antibodies. Proc. 8th Congress of Italian Society of Diabetology, Naples, p 479-480

47. Ortved Andersen O (1976) Anti-insulin antibodies and late diabetic complications. Acta Endocrinol (Kbh) 83: 329-340

48. Page-Faulk W, Karam JH, Fudenberg HH (1971) Human antiinsulin antibodies. J Immunol 106: 1112-1116

49. Jayarao K, Page Faulk W, Karam JH, Grodsky GM, Forsham PH (1974) Evidence in support of the concept of immune complex disease in insulin treated diabetics. In: Bastenia PA, Gepts W (eds) Immunity and Autoimmunity in diabetes mellitus. Excerpta Medica, Amsterdam, p 255-263

50. Andreani D (1980) Malignant microangiopathy. Diabetologia 18: 255

Received: May 2, 1980

U. Di Mario, M. D.

Cattedra di Endocrinologia

Clinica Medica II

Policlinico Umberto I

I-00161 Roma

Italy 